\title{
中国毛烏素沙地における衛星画像を用いた植生量 および放牧圧の推定
}

\author{
Estimation of Vegetation Biomass and Grazing Intensity Using Remote Sensing Data in Mu-Us \\ Desert, China
}

\author{
國友淳子* 吉川 賢 ${ }^{* *}$ 森本幸裕 ${ }^{* *}$ \\ Junko KUNITOMO Ken YOSHIKAWA Yukihiro MORIMOTO
}

\begin{abstract}
摘要：中国内蒙古自治区の毛烏素沙地における持続的な土地利用を検討していくために，現地の牧農 家から放牧に関するアンケート調查を行い，現在の放牧状況を把握した。また，その結果と衛星画像 データ（SPOT/HRV）を組み合わせて, 広域的な放牧圧の推定方法を検討した。その結果, 放牧に よる土地利用では, 夏と冬で利用する土地類型を換えていること, 夏に 2 つ湿性草原を交互に利用 していることがわかった。衛星画像から作成した現存量画像からは, 放牧頭数からだけでは判断しにく い過放牧の影響を明らかにすることができた。現存量画像と植物生産量との回帰式を画像へ適用する ことにより，広域的な放牧負荷率の推定および特定地域の放牧管理に利用できることが示唆された。
\end{abstract}

\section{はじめに}

砂漠化および土地荒廃は, 気候条件, 土壌構造, 地形などの自 然的要因に加え，その地域の人口や土地利用形態などの社会経済 的・人為的な要因によって引き起こされている。世界の乾燥地域 で砂漠化／土地荒廃の影響をうけている土地利用形態は, 潅溉農 地, 降雨依存農地, 放牧地であり，そのうち放牧地（約 33 億 3,300 万 ha）(最む広い1。このような人間活動による砂漠化 ／土地荒廃を防止するためには, 植生の活性状況之人為的要因之 の関係を明らかにして, 生態学的にバランスのとれた土地利用シ ステムを考える必要がある。

本研究の対象地域である中国内蒙古自治区にある毛鳥素沙地は 半乾燥地域であり, モンゴル民族が多く定住し, 主に牧畜業が行 われている。この地域は歴史時代の戦争や過放牧, 粗放な開裂等, 人為的要因により砂漠化が進行した。近代では人民政府成立後, 数回にわたる濫墾過牧が行われたために, さらに植生が退行し, 流砂が増大した ${ }^{2,33}$ 。現在では, 定住化政策や 1980 年代前半の人 民公社の解体之農業生産責任制により，1 人あたりの羊の平均所 有数が増大した ${ }^{4}$ 。これは地域住民が経済的に自活していくため に必要なことであるが, 過放牧による植生の過剩利用や気候变動 にともなう植生の退行が危惧されている。

これまでに筆者らは, 衛星画像を用いて広域的な植生の活性状 況の季節変動 ${ }^{5}$ やさまざまスケールで土地被覆分類図を作成し，

毛鳥素沙地のランドスケープ構造を示した ${ }^{6)}$ 。

本研究ではランドスケープ構造に沿った土地利用を検討してい くために, 現地の牧農家から放牧に関する聞き取り調查を行うこ とにより, 現在の放牧状況を把握し, その結果之衛星画像デー夕 を組み合わせて, ある地域の植生がどの程度の放牧インパクトを うけているかを推定した。

\section{1. 調查対象地の概要}

調査対象地は中国内蒙古自治区のオルドス高原（標高 1,000 $1,500 \mathrm{~m}$ ) 南部に, 400 万 ha に渡って広がる毛烏素沙地である （図-1 ）。この地域の地質的基盤は, 中生代起源の砂岩層であり, この風化物あるいは水侵食による堆積土砂が現在の砂の起源であ る $^{2)}$ 。大小の半月型砂丘が存在し，砂丘砂は冬期および春期の北 西螷によって移動する。気候条件は, 年平均気温 $6.4^{\circ} \mathrm{C}$, 年平均 降水量 $362 \mathrm{~mm}$ であり, 降雨は 6 〜 月に集中する。
毛烏素沙地に成立する植生は，土壤・地形等と強く結びついて 成立している。地形を基礎とした土地類型は景観に反映しており， 移動砂丘地・固定砂丘地 - 半固定砂丘地 - 湿性草原 - 波上高平原 に分類される。SPOT/HRV データを用いて行った教師付き分類 図（図ー2）では，現地の景観に類似した11 クラスを確認した。 各クラスの面積割合は, 移動砂丘地が約 30\%を占め, ここでは植 被がほとんどみられない。その周辺には砂漠化の危険性の高い半 固定砂丘地や低密度草原が広がる。固定砂丘地では砂の移動は少 なく, 臭柏 (Sabina vulgaris) の常緑潅木林や, 油䒾 （Artemisia ordosica）を代表種とする落葉潅木林が成立してい る。湿性草原では, イネ科のヨシ (Phrgmites communis), 拂 子茅 (Calamagrostis epigeops), 寸草 (Carex stenophlla), キク科のPotentilla sp.などがみられる。

\section{2. 研究方法}

\section{（1）アンケート調査}

内蒙古自治区伊克昭盟鳥審旗図克蘇木桃包の地域の牧農家に対 して，土地利用方法に関するアンケート調査を行った。図克蘇木 は毛烏素沙地の北東部に位置し，面積 109,580ha，1991 年にお ける世帯数は 968 「であった。調査は 1999 年の 8 月下旬に, 毛 鳥素沙地開発整治研究センターの近隣に定住する7户の牧農家の,

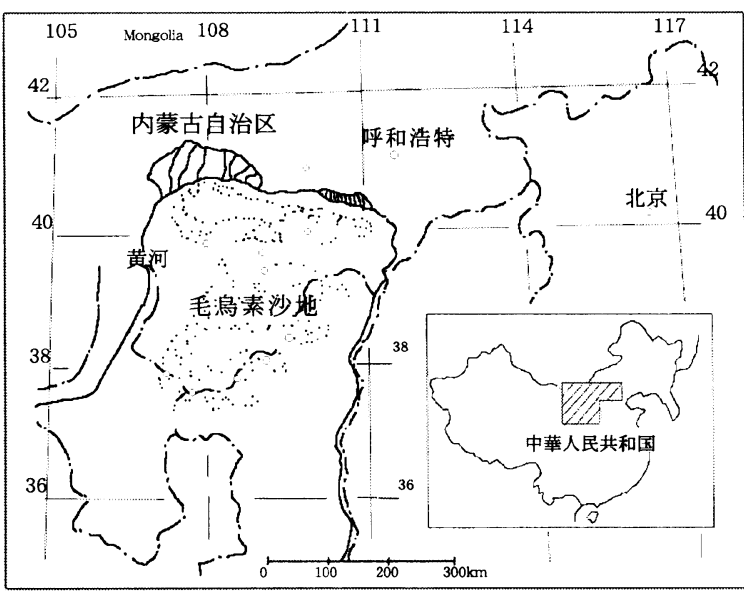

図一 1 調査地 
実際に農牧業に従事している人を対象に行った。アンケートを行っ た牧農家の緯度経度をGPS カメラを用いて測定し, 図一 2 に示 した。アンケートの内容は, 所有地面積, 家畜頭数, 土地利用の 方法に関する設問, 緑化活動に関する設問, また「今後どのよう に牧農業を発展させていきたいか」といった要望の設問も含めた。 所有地面積は上記の土地類型ごとに聞いたが, ほとんどの牧農家 は総面積之草場（湿性草原之固定砂丘地）についての概数（畧： ムー）または比率で記憶しているため，その数值を解析に供した。 聞き取りを行った 7 戸は, 所有地面積から判断して, この地域の 小規模から大規模な牧農家をカバーしている。

（2）SPOT/HRV データを用いた放牧地における現存量の推定

現存量の推定には, 1997 年 6 月 22 日に撮影されたSPOT/ HRV デー夕（空間分解能 : $20 \mathrm{~m}$ ) から作成した NDVI 画像と TSAVI 画像を用いた。湿性草原 (meadow, reedswamp, wet lowland）の地上部現存量を求めるために, 現地調査から 得た湿性草原の NDVI - 地上部現存量の回帰式 ()を用いて, NDVI 画像から地上部現存量画像を作成した。固定砂丘地に成 立する落葉樹林 (deciduous forest) および落葉潅木 (deciduous shrub) については, 固定砂丘地に成立する群落（油蒿, 沙 柳, 楊柴) の TSAVI-地上部現存量の関係を対数曲線にあては めて回帰式を求め（図-3), さらに飼料となる同化部現存量を 推定するために, 地上部現存量一同化部現存量の関係式 (図一-3) を用いて, TSAVI 画像から同化部現存量の画像を作成した。植 生指数 TSAVI (Transformed Soil Adjusted Vegetation Index）は，低密度の植生被覆地域におけるバックグラウンド土 壤の反射特性による八イズを軽減するために考案された指数 ${ }^{8)}$ で ある。地上部現存量を推定するために, 湿性草原と固定砂丘地で 用いた植生指数が異なる (NDVI と TSAVI) のは, 各指数と地 上部現存量との相関を調べ, 相関係数の高い方を選択したためで ある。バイオマス量の推定は, アンケート調査を行った牧農家の ある地域を含む $12 \mathrm{~km} \times 12 \mathrm{~km}$ の範囲で行った。

\section{3. 結果および考察}

(1) 放牧に関するアンケート結果

毛鳥素沙地開発整治研究センターの近隣に住む牧農家を対象に 行ったアンケートの結果を表 -1 に示す。

定住年数は各牧農家によって異なっており, 約 100 年という牧 農家むあったが, NO. 3，5，6のような解放後の大躍進の頃や NO. 1 のように人民公社解体後に入植してきた牧農家が多いと思
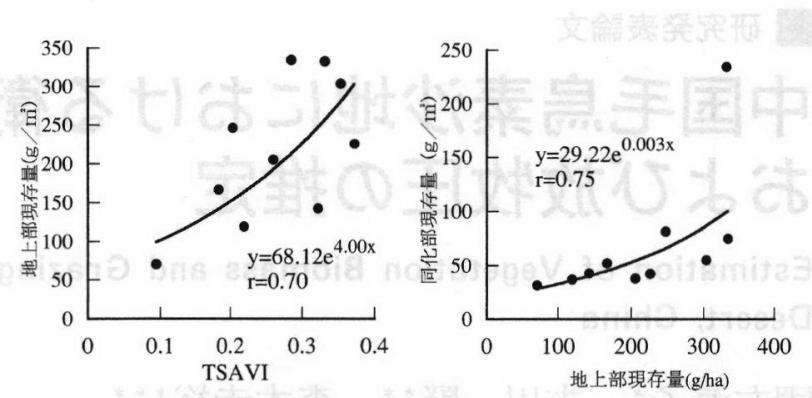

図－3 固定砂丘地に成立する植物群落の TSAVI-地上部 現存量および地上部現存量一同化器官現存量の関係

われる。所有地面積は, 古くから定住している農家では2000ムー （133ha）以上を有していた。放牧ができない流動砂丘地の面積 割合は平均 $48 \pm 9.1 \%$ で, この值は図 -2 の流動砂丘と半固定砂 丘地を合わせた面積割合（45\%）と類似しており，これらの土地 は放牧地として利用していないことがわかる。

土地利用のローテーションについては, 全牧農家で夏期 ( 5 10 月）と冬期（11〜 4 月）に分けてローテーションを行ってお り, 夏期は湿性草原, 冬期には固定砂丘地を利用していた。湿性 草原は, 図-2 の土地被覆タイプの meadow や reedswamp, wet lowland である。湿性草原を 1つしか持っていない牧農家 は，その 1 つに全ての羊・ヤギを放牧し，2つある牧農家では， 3 力月, 2 力月, または 15 日ごとに輪換放牧を行っていた。冬 期に利用する固定砂丘地の土地被覆夕イプは, 図-2の deciduous forest や shrubであり, 牧羊は油蒿や沙柳（Salix cheilophila）の枯葉を採食し, さらに夏の間に刈り取った旱柳 （Salix matsudana）の葉を飼料にしていた。

羊・ヤギの平均家畜頭数をみると, 放牧地 (湿性草原と固定砂 丘地）では, $2.5 \pm 1.2$ 頭/ ha, 湿性草原では羊・ヤギで $4.9 \pm 1$. 9 頭 /ha であった。1990 年の図克蘇木の統計資料から計算した 平均家畜頭数は, 1.2 頭/ ha であり, 聞き取りによっても牧羊 数は増加傾向にあるとのことだった。この家畜頭数について, 毛 鳥素沙地と類似した気象条件の内蒙古自治区内のカルチン沙地 （平均気温 $6.4^{\circ} \mathrm{C}$, 降水量 $372 \mathrm{~mm}$ ）において行われた実験を参考に 評価をしてみる。放牧頭数を 3 段階（6頭，4 頭， 2 頭 $/ \mathrm{ha}$ と 禁牧区）に設定して 5 月〜 9 月に 5 年間，放牧を行った実験では， 禁牧区の現存量が $350 \mathrm{~g} / \mathrm{m}^{2}$ であるのに対し， 6 頭 $/ \mathrm{ha}$ 程度の 放牧圧で $30 \mathrm{~g} / \mathrm{m}^{2}$ 程度まで減少した。また, 起伏量・比高の大
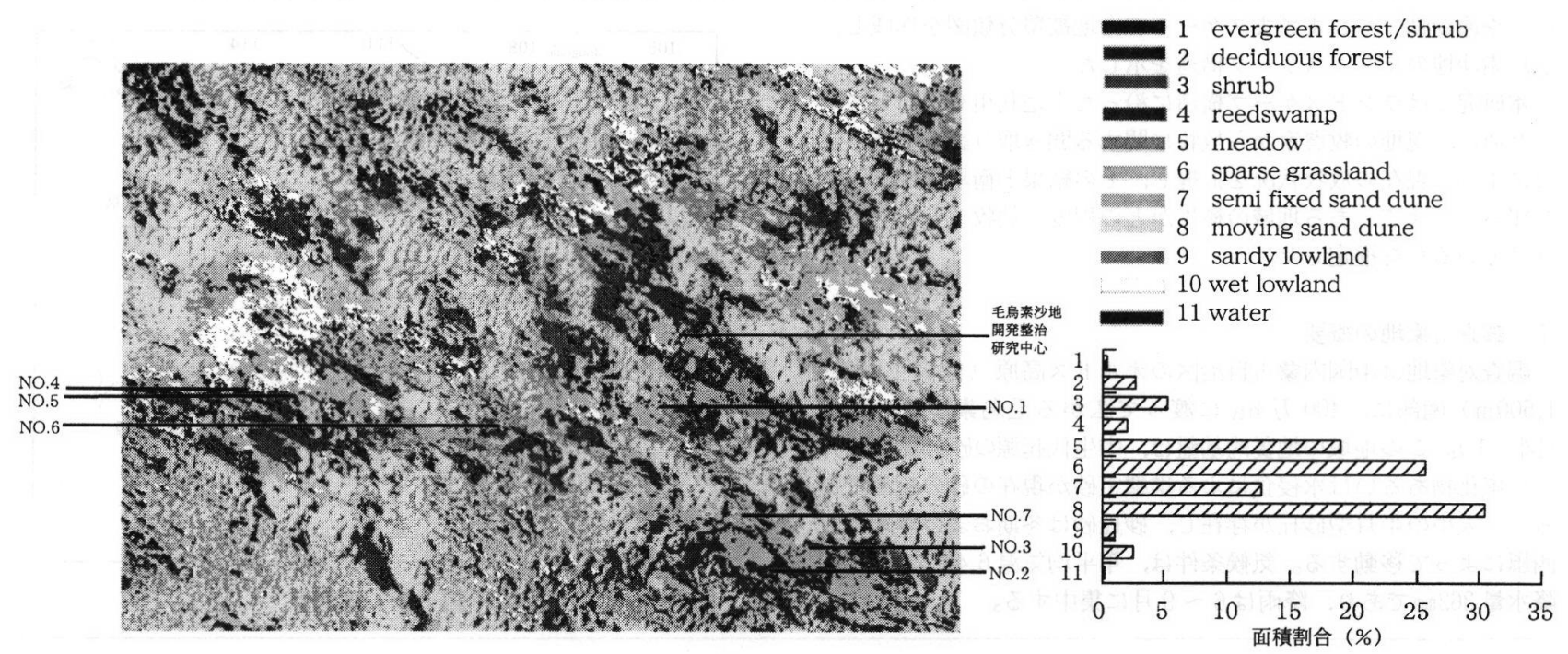

図ー2 アンケート調查を行った地域の土地被覆分類図 
表ー 1 アンケート調査結果

\begin{tabular}{|c|c|c|c|c|c|c|c|c|c|}
\hline & & NO.1 & $\mathrm{NO} .2$ & NO.3 & NO.4 & NO.5 & NO.6 & NO.7 & 平均 \\
\hline 定住年数 & & 17 & 約 100 & 33 & 約 100 & 37 & 43 & 約 $90 \sim 100$ & \\
\hline 所有地面積(ha) & 湿性草原 & $25.2(27)$ & $86.7(33)$ & $33.3(25)$ & $66.2(25)$ & $13.3(22)$ & $36.2(27)$ & $32.8(25)$ & $42.0 \pm 25.4$ \\
\hline \multirow[t]{4}{*}{ （）内は割合 } & 固定砂丘地 & $18.1(19)$ & $93.3(35)$ & $31.3(24)$ & $66.2(25)$ & $10.0(17)$ & $36.2(27)$ & $32.8(25)$ & $41.1 \pm 29.0$ \\
\hline & 耕地 & $3.3(4)$ & $6.7(3)$ & $2.0(2)$ & $2.0(1)$ & $0.9(2)$ & $0.8(1)$ & $1.0(1)$ & $2.3 \pm 2.1$ \\
\hline & 流動砂丘地 & $46.7(50)$ & $80.0(30)$ & $66.7(50)$ & $132.4(50)$ & $35.7(60)$ & $60.0(45)$ & $66.7(50)$ & $69.7 \pm 31.2$ \\
\hline & 合計 & 93.3 & 266.7 & 133.3 & 266.7 & 60 & 133.34 & 133.34 & $155.2 \pm 80.8$ \\
\hline 湿性草原の数 & & 2 & 2 & 2 & 2 & 1 & 2 & 2 & \\
\hline 放牧地あたりの & (羊+ヤギ)/ha & 3.5 & 2.1 & 3.1 & 1.1 & 4.5 & 1.9 & 1.6 & $2.5 \pm 1.1$ \\
\hline 家畜頭数 & 牛/ha & 0.8 & 0.2 & 0.0 & 0.2 & 0.3 & 0.1 & 0.1 & $0.2 \pm 0.3$ \\
\hline 湿性草原あたりの & (羊+ヤギ)/ha & 6.0 & 4.4 & 6.0 & 2.3 & 7.8 & 4.7 & 3.1 & $4.9 \pm 1.9$ \\
\hline 家畜頭数 & 牛/ha & 1.2 & 0.3 & 0.0 & 0.3 & 0.5 & 0.2 & 0.1 & $0.4 \pm 0.4$ \\
\hline 固定砂丘地 & (羊+ヤギ)/ha & 7.0 & 3.2 & 5.1 & 1.7 & 7.4 & 3.3 & 2.5 & $4.3 \pm 2.2$ \\
\hline あたりの家畜頭数 & 牛/ha & 1.9 & 0.3 & 0.0 & 0.3 & 0.6 & 0.2 & 0.1 & $0.5 \pm 0.7$ \\
\hline 農作物の種類 & & 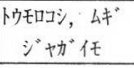 & $\begin{array}{c}\text { トウモロコシ, } \\
\text { アワ }\end{array}$ & $\begin{array}{c}\text { トウ氏吹， } \\
\text { アワ }\end{array}$ & $\begin{array}{c}\text { トウ吹シ，Pワ } \\
\text { ジ咕任 }\end{array}$ & $\begin{array}{c}\text { トウチロコシ，阿 } \\
\text { ジ切任 }\end{array}$ & $\begin{array}{l}\text { トウモロコシ，アワ } \\
\text { ジ咕”任 }\end{array}$ & $\begin{array}{c}\text { トウ氏ロコシ, アワ } \\
\text { 叹メ }\end{array}$ & \\
\hline 農業を始めた年 & & 1987 & 1980 & 1982 & 1982 & 1983 & 1982 & 1980年代始め & \\
\hline
\end{tabular}

きい場所では 4 頭 / ha 程度の放牧圧でも裸地化が始まるという 結果が報告されている ${ }^{8), 9)}$ 。これらから判断すると, NO. 1 や 5 の牧農家では, 平均家畜頭数が大きく, これ以上の家音頭数の増 加によって, 湿性草原における植生退行の恐れがある。

緑化活動に関する設問では，流砂固定のために全牧農家で毎年， 流動砂丘地や固定砂丘地に旱柳や沙柳の挿木造林を行っていた。 また半固定砂丘地には，栭条（Caraganakorshinskii）(挿木), 楊柴 (Hedysarum mongolicum) (種子と挿木), 油蒿（挿木） による緑化を行っていた。牧草として利用するために, 固定砂丘 地抢よび湿性草原にマメ科の草木栖 (Melilotus suaveolens), 沙打旺 (Astragalus adsurgens) を植えていた。

農業生産についてみると, どの牧農家も畑地を持ちトゥモロコ シ（飼料用）やアワ（食用）, ジャガイモ（食用上飼料用）を主 に栽培していた。農業生産を始めたのは 1980 年代初頭であり, その面積を徐々に広げてきた。開墾を行う場所は固定砂丘地之灘 地の間であり, 耕作には地下水を汲み上げて潅溉を行っている。

今後の要望については, 舎飼による安定した牧音経営を行いた いという牧農家が多く, 飼料用作物のための畑地を拡大し, 沙柳 や旱柳などの植林を行うことによって, 飼料生産を増加させるこ とを目標としていた。

\section{（2）衛星画像による放牧地の現存量の推定}

夏期の放牧地である湿性草原の地上部現存量画像および, 冬期 の放牧地である固定砂丘地の同化器官現存量の画像を図 -4 に示 す。この画像から求めた湿性草原の平均地上部現存量は $220 \mathrm{~g} /$ $\mathrm{m}^{2}$, 固定砂丘地の同化器官の平均現存量は $51 \mathrm{~g} / \mathrm{m}^{2}$ あっった。

次に現存量画像を用いて, 湿性草原における放牧のインパクト
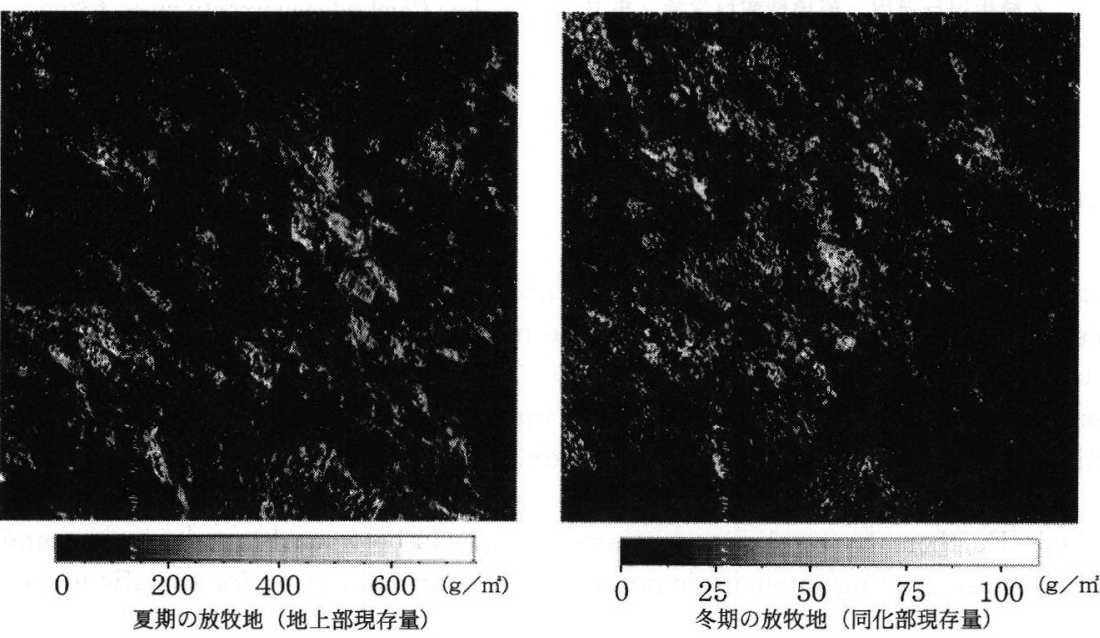

図-4 放牧地の現存量画像
を以下の式 ${ }^{10)}$ から求めた。

被食量 $\left(\mathrm{g} / \mathrm{m}^{2}\right)=$ 放牧家音頭数 $\left(\right.$ 頭数 $\left./ \mathrm{m}^{2}\right) \times 1,500 \mathrm{~g} \times$ 放牧日数 生産量 $\left(\mathrm{g} / \mathrm{m}^{2}\right)=$ 被食量 + 平均地上部現存量（画像値）

負荷率 $=$ （被食量 $/$ 生産量） $\times 100$

衛星画像から作成した現存量画像の值は, 家畜による被食量が引 かれた值である。そこで被食量として羊が 1 日に食べる草量を $1,500 \mathrm{~g}$ とし, 牛については 1 頭を羊 5 頭に換算して, 放牧日数 は夏期に湿性草原で放牧を行う日数を入れて計算した。生産量は 被食量に平均地上部現存量（画像値）を加算して求めた。これは 衛星画像が撮影された 6 月 24 日の地上部現存量を夏期の増加量 とみなして計算したものである。このようにして求めた被食量と 生産量加負荷率を求めた。今回の現地調査では各牧農家の所有 地の境界線を把握できなかったため, GPS カメラで調べた牧農 家の家の位置付近における平均現存量值を用いた。

これらの值を表 -2 に，また平均地上部現存量（画像値）と生 産量の関係を図 -5 に示す。表 -2 を見ると, 被食量は牧農家ご との湿性草原あたりの平均家畜頭数（頭 $/ \mathrm{ha}$ ）によって異なる。 図一 5 をみると, 平均地上部現存量と生産量の間には, 正の相関 がみられる。負荷率は平均 44\%で，32\%～56\%までの幅がある。 被食量が大きい NO. 1 やNO. 5 で, 負荷率も大きい值を示した が，NO. 2 のように被食量が小さくても負荷率が大きい湿性草原 ああることがわかる。これは, 湿性草原ごとに放牧可能な容量が 異なっていることやこれまでの放牧圧が高かったために植生量が 減少してきていることが推測される。単に放牧頭数からだけでは 判断しにくい過放牧の影響を, 衛星画像から求めた現存量の值を 用いることによって, 放牧による負荷率から定量的に各牧農家ご とに判断できる。

図-5 の回帰式を湿性草原の現存量画像に 適用して得られた值は, 平均生産量 $410 \mathrm{~g} /$ $\mathrm{m}^{2}$, 平均被食量 $191 \mathrm{~g} / \mathrm{m}^{2}$, 平均放牧頭数は 羊，ヤギで 5.4 頭 $/ \mathrm{ha}$, 負荷率 0.48 であっ た。画像から推定した湿性草原における放牧 頭数および負荷率のヒストグラムを図ー6に 示す。放牧頭数は $4 \sim 6$ 頭 $/ \mathrm{ha}$ でピークが みられる。1991 年の図克蘇木のデー夕から 求めた湿性草原における平均放牧頭数は, 2.7 頭/ ha であり, この地域で放牧頭数が 増加していることが予想される。負荷率のピー クは，0.46〜0.47であるが 0.58 という高い 負荷率を示すピクセルむあり, 放牧圧の強い 地域があることがわかる。

以上のような手順で, アンケート調査の結 果をもとに, 衛星画像から生産量, 被食量, 
表－2 夏期の湿性草原における植生への負荷率

\begin{tabular}{l|cccccccc}
\hline & NO.1 & NO.2 & NO.3 & NO.4 & NO.5 & NO.6 & NO.7 & 平均 \\
\hline \hline 被食量 $\left(\mathrm{g} / \mathrm{m}^{2}\right)$ & 329 & 161 & 166 & 104 & 278 & 152 & 104 & $185 \pm 896$ \\
\hline 生産最 $\left(\mathrm{g} / \mathrm{m}^{2}\right)$ & 590 & 306 & 390 & 327 & 500 & 428 & 282 & $403 \pm 112$ \\
\hline 負荷率 & 0.56 & 0.53 & 0.42 & 0.32 & 0.56 & 0.36 & 0.37 & $0.44 \pm 0.10$ \\
\hline
\end{tabular}

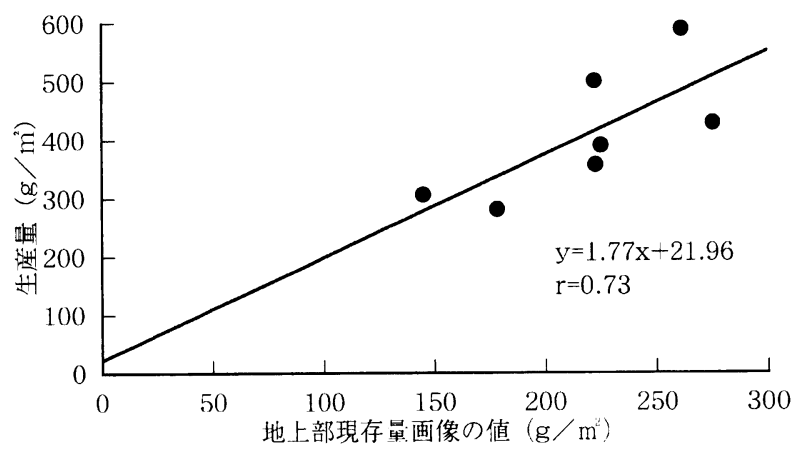

図一 5 平均地上部現存量－生産量の関係

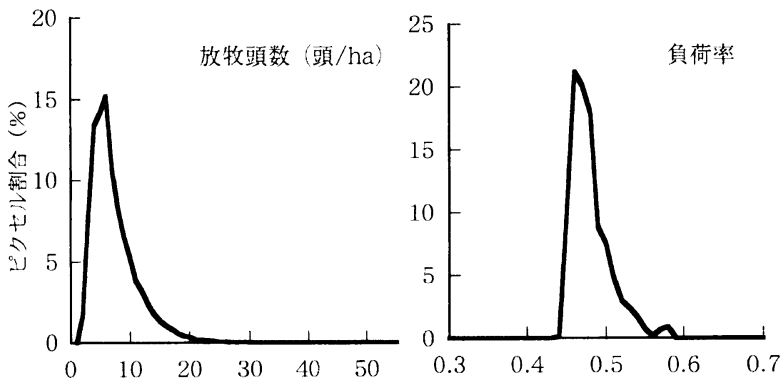

図-6 画像から推定した放牧頭数と負荷率のヒストグラム

放牧頭数, 負荷率を求め, どの地域で過放牧の恐れがあるか, 推 定できることが示唆された。しかし，今回はアンケートのサンプ 儿数が少なく，また裸地化が抢きる湿性草原の被食量の上限が明 らかになっていない。今後は，サンプル数を増やし，湿性草原に
おいて裸地化が進む位置での放牧頭数を明らかにする必要がある。

\section{4.まとめ}

放牧地における砂漠化・土地荒廃の進行は, 植生の退行による あのであるが，これを防ぐためには，適切な放牧頭数の管理を行 うことにより，植生を保全しなければならない。その場合，いく つかの放牧地を利用してローテーションシステムを取り入れ，ど れくらいの強度と時間間隔でローテーションすれば, 持続的な家 畜生産を行えるのかを検討する必要がある ${ }^{137}$ 。アンケート調査を 行った地域では，夏期と冬期で放牧を行う土地類型が異なってお り, また灘地を 2 つ以上所有している牧農家では, 夏期に輪牧放 牧を行っていた。輪牧放牧は放牧のインパクトを分散させるのに 効果的であり，家畜は植物種に対して晴好性があることから ${ }^{12)}$, それらの集中的な減少を緩和させることができる。湿性草原を 2 つ所有している牧農家は輪換放牧ができるが, 1 つしか湿性草原 を持っていない牧農家は輪換放牧ができない。このような場合, 家畜頭数を増加していくことは難しく, 草原の現存量を効率的に 利用する方法を考えなければならない。その方法としては, 灘地 に 1 年または数年間の禁牧区の設置, 湿性草原と固定砂丘地にお ける緑化等があげられる。放牧を行わない期間を設けることによっ て, 植物生産量の増大と種組成の変化が見込まれており ${ }^{11), 44}$, 有 効な方法であるが，放牧区の放牧密度が高くなるためにおこる裸 地化の程度を見極めて, 土地荒廃に気をつけなければならない。 ローテーションシステムについては, 禁牧区を設置した場合の変 化のデータや時系列の負荷率デー夕を積み重ねることによって効 率的に草地を利用できる方法を検討していく必要がある。

\section{謝辞}

現地調查の際, 内蒙古農業大学, 毛鳥素沙地開発整治研究中心 の方々および岡山大学坂本圭児先生ら調查隊のメンバーにご協力, ご指導を頂いた。ここに記して，感謝の意を表します。

\section{参考文献}

1) 地球環境研究センター (1997) : Data Book of Desertification / Land Degradation : 環境庁 国立環境研究所, $68 \mathrm{pp}$

2) 小橋澄治 (1986): 内蒙古自治区毛烏素沙地 緑化利用の状況：緑化工技術 $11(3), 15-22$

3 ) 河野通博 (1988): 中国に抢ける砂漠化とそ の防治についての覚書 : 地理学評論 61(2), 186-197

4 ) 内蒙古沙漠開発研究会 (1992): 中国の乾燥 地に扔ける砂漠化防止に関する実証的研究： 卜ヨ夕財団助成研究報告書, $212 \mathrm{pp}$

5 ) 國友淳子・森本幸裕 (1999)：リモートセン シングによる中国毛烏素沙地における植生 量の定量的評価と季節変動の解析: 環境情 報学論文集 $13,115-120$

6) Junko Kunitomo - Yukihiro Morimoto (1999): Vegetation monitoring using dif- ferent scale of remote sensing data. : Jour. of Environmental Science 11(2), 216-220

7 ) 國友淳子 - 森本幸裕（1998）：分光反射特性 による毛烏素沙地植物群落の生育診断：日 本造園学会誌 61(5)，577-580

8 ) Baret F • Guyot G. (1991): Potentials and Limits of Vegetation Indices for LAI and Apar Assessment. Remote Sens. Environ. No.35, 161-174

9 ) 大黒俊哉・根本正之 (1996)：中国北東部半 乾燥地地域の砂地草原における過放牧によ る植生退行過程: 環境情報科学論文集 10 , $31-36$

10）農水省農業環境技術研究所・農業総合研究 所: 砂漠化防止対策適用効果の評価手法の 開発に関する研究 : 環境宁地球環境研究総 合推進費終了研究報告書

11) Toshiaki Imagawa et al.(1998): Estimati on of Biomass and Grazing Intensity for Grassland in Naiman, Inner Mongolia, China using Remote Sensing : Proceedings of Japan-China Workshop on Land Evaluation of Prevention and Remedies for Desertification

12）根本正之・大黒俊哉 - 徐斌 - 趙哈林 (1994)：緬羊の放牧強度の違いが数種草原 植物の生育に及ぼす影響：日本草地学会誌 40(3), 239-245

13) Richard T.T.Forman (1995): Land Mosa ics : Cambridge university press, $632 \mathrm{pp}$

14) E.J. Mwendera - M.A. Mohamed Saleem • Zerihun Woldu (1997): Vegetation response to cattle grazing in the Ethiopian highlands : Agriculture, Ecosystem and Environment 64, 43-5

Summary : We conducted interview through questionnaires from stock farmers about the method of land use for stock farming in semi-arid region of $\mathrm{Mu}$-Us desert in China. Additionally, land use method was evaluated by analysis of SPOT/HRV image of ground biomass using vegetation indices (NDVI, TSAVI). There is rotational type of land use; grassland on wet lowland is used for grazing in summer; in winter, deciduous forest and shrub on fixed sand dune are used. During summer, most farmers utilize the lowland grassland in alternation. Although it is possible to estimate over-grazing from the number of livestock only, by using biomass image and carrying capacity of the land, the grazing intensity of each land unit could be identified. Further, by applying regression analysis between biomass image and total production of a site, broad area estimation of grazing intensity is possible hence land planning for specific a area can be carried out. 